\title{
PRICE STABILITY OF AGRICULTURAL PRODUCTS IN THE EUROPEAN UNION
}

\author{
Boris Spasojević1, Aleksandar Đukić2, Ognjen Erić3 \\ *Corresponding authorE-mail: djukicaleksandar84@gmail.com
}

A R T I C L E I N F O
Review Article
Received: 25 October 2018
Accepted: 02 November 2018
doi:10.5937/ekoPolj1804585S
UDC 338.532.4:338.432(4-672EU)

Keywords:

Prices, Common Agricultural Policy, objectives, goals, support, European Union

JEL: $Q 100, Q 110$

\section{A B S T R A C T}

Agricultural sector in the EU functions under strong influence of the CAP. EU finances the measures to support production of agricultural products and food. CAP is founded on the goals of ensuring price stability. Correlation and regression analysis have largely confirmed the given hypotheses. General price levels in EU, as well as the prices of agricultural products have been stable, as shown by the respective trend line equations. Correlation and regression analysis of support for agricultural production and prices of agricultural products indicate a moderate correlation level, i.e. the support contributes to price stability. Correlation analysis confirms the influence of prices of industrial products on the prices of agricultural products. Results of price movement analysis of agricultural products and foods on one hand, and independent variables affecting prices on the other, show that CAP objectives have been mainly accomplished. Thus, interventionism in agriculture brings economic effects and justifies the CAP measures.

(C) 2018 EA. All rights reserved.

\section{Introduction}

Measures of the Common Agricultural Policy (CAP) of the European Union (EU) financially support the production of agricultural products and food. The objectives of the CAP have been defined back in the Treaty of Rome. CAP has created a modern and productive market for agricultural products and food, built on the tradition and high standards of production, processing and transport. Namely, in the creation of CAP instruments, little concern was paid to the level of protectionism and possible distortion in the trade with the rest of the world (McMhanon, 2007). After all, the primary reason for the concern for agriculture was strategic: to ensure own food production. The

1 Mag. Boris Spasojević, Mag.Econ, Catering, Trade and Tourism Vocational School, Banja Luka, Bosnia and Herzegovina, dr Mladena Stojanovića 117a, 78000 Banja Luka, phone no.: +387 65443 747 , E-mail: borisspasojevic@yahoo.com

2 Aleksandar Đukić, B.Sc.Hon.Econ., Catering, Trade and Tourism Vocational School, Banja Luka, Bosnia and Herzegovina, Kosovska bb, 78000 Banja Luka, phone no.: +387 65561 489 , E-mail: djukicaleksandar84@gmail.com

3 Ognjen Erić, PhD. Krajinapetrol inc. Banja Luka, Gundulićeva 98, 78000 Banja Luka, phone no.: +38765979313 , E-mail: ognjeneric@yahoo.com 
second reason is the assumption that if a country is able to meet basic food needs (as is the case with developed market economies), the price elasticity of demand (Edp) for food would be less than 1 (Jovanović, 2013). Such inelasticity affects the price decline (p) of agrarian products and foods as the supply / quantity (q) of supply increases as per following formula:

$\mathrm{E}_{\mathrm{dp}}=\frac{\Delta_{q / q}}{\Delta p / p}=\frac{\Delta_{q p}}{\Delta p q}=<1$

Ultimately, the relative price of food in developed economies decreases due to low price elasticity, but also due to demand elasticity (Y) which is less than 1 , that is:

$\mathrm{E}_{\mathrm{dp}}=\frac{\Delta_{q / q}}{\Delta y / y}=\frac{\Delta_{q p}}{\Delta_{p q}}=<1$

Naturally, agricultural production is affected by natural conditions. Today, the CAP is an environmentally responsible and socially responsible policy, expected to deliver an effective production system competitive in the world market (Quiroga, Suarez, Fernandez Haddad, Philippidis, 2017). The CAP is being modernised through reforms, from MacSharry to the present day. Therefore, the old and reformed goals of the CPA can be achieved by stimulating production growth as the supply growth, i.e. higher production level of agricultural products tends to stabilize prices. Secondly, lower prices may lead to the growth of real demand for agricultural products (Popović, 2016), as shown in the following chart.

Figure 1. The impact of agricultural policy on supply and demand

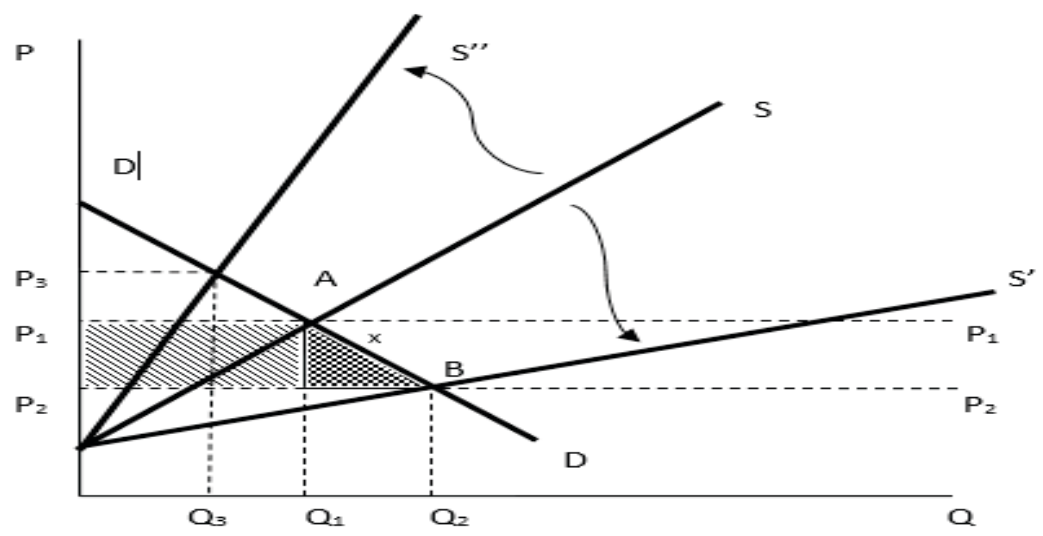

Source: Representation by the authors

The above graph shows that the growth of supply from $S$ to $S$ ' leads to price drop from $\mathrm{P} 1$ to $\mathrm{P} 2$. Therefore, in the case of constant demand, consumers may buy more products for the same amount (Q2). Analogously, the drop in the S' supply increases the prices to P3 level. The consumer surplus is shown by the P1P2BA area. This is a simple analysis as it does not include additional constraints. 
Interventions of CAP and their impact on prices. Agricultural support is an instrument for accomplishing the general objectives of agricultural policy (Hansen, 2015). Price policy in agriculture is either directly or indirectly implemented by the CAP measures. The prices strongly affect the agriculture of EU (Walls, Cornelsen, Lock, Smith). However, in the early stages of the EC, there were problems, such as, hyperproduction of butter production due to high intervention prices. Fast and profound CAP reforms, alongside with the respective pricing policy, included control of imports and other measures (Riccardi, F., 2001). The events that caused disturbances in the market have been supplemented and redefined over time (Bureau, Swinnen, 2018). Import and export of agricultural products and foods affect price stability. If there is a price increase in the EU market, there will be increase in imports at lower global prices. If the world prices rise above the standard prices, exports will increase (Ostashko, 2016). Reforms reduce the disproportion between supply and demand in the agricultural product market (Kotulic, Dubravska, 2015), whereas their sufficient quantities provide stable prices. Furthermore, the growth of real income influences real food prices, as can be seen from the hypothesis of Prebisch-Singer and Engel's law (Baffes, Haniotis, 2016). Finally, consumer prices in the EU Member States indicate differences in the structure and efficiency of their food markets (García-Germán, Bardaji, Garrido). The following graph shows the theoretical aspects of CAP interventions and price policy.

Figure 2. Interventions and prices of agricultural products

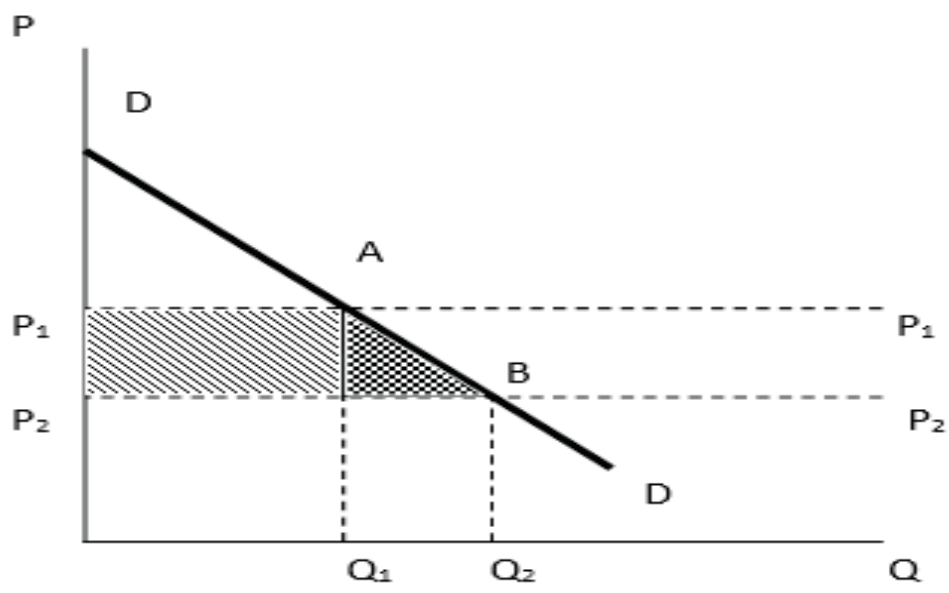

Source: Representation by the authors

The result of the intervention is the price drop from point $\mathrm{A}$ to point $\mathrm{B}$. The intervention creates consumer surplus P1P2BA. Under the assumption of the same purchasing power, the consumers may purchase more goods for the same amount (Q1 moves to Q2). There is a strong link between the CAP intervention and the price of agricultural products and food in the EU. Deviations created as a result of interventions are resolved through new CAP measures. 
The statistical analysis shall include a correlation and regression analysis model, whereby each value of a phenomenon corresponds exactly to a specific value of the second phenomenon. Statistical or stochastic relations (links) are weaker in comparison to the functional ones. Regression analysis consists in the application of methods which utilise analytical (by means of equation) explanation of the statistical link between the observed phenomena. The regression analysis assessed the cause-effect nature of the relationship (independent and dependent variables). The analysis is based on the regression model. The equation with parameters and variables explain the connection of the observed phenomena, predicting the values of the dependent variable for certain values of the independent variable. There are two models, which are a simple regression model and a multiple regression model. The simple linear regression model analytically displays the relationship between two phenomena (dependent and independent variable). The model feature is that the change of a phenomenon is followed by the approximately same linear change of the second phenomenon.

The equation of the first regression direction: $Y c=a+b \cdot x$

$$
\mathrm{b}=\frac{\Sigma X Y-\bar{X} \Sigma X}{\Sigma X^{2}-\bar{X} \Sigma X} \quad \mathrm{a}=\bar{Y}-\mathrm{b} \cdot \bar{X} \quad \bar{X}=\frac{\Sigma X_{i}}{N} \quad \bar{Y}=\frac{\Sigma Y_{i}}{N}
$$

Calculation of parameters:

The linear correlation coefficient (Pearson correlation coefficient) is a numerical measure of the strength and direction of the interconnection between the two phenomena that are placed in a linear statistical correlation. The coefficient formula is:

$$
\begin{aligned}
& \mathrm{r}=\frac{\Sigma\left(X_{i}-\bar{X}\right) \cdot\left(Y_{i}-\bar{Y}\right)}{\sqrt{\Sigma\left(X_{i}-\bar{X}\right)^{2} \cdot \Sigma\left(Y_{i}-\bar{Y}\right)^{2}}} \quad \text { Spearman's rank correlation coefficient: } \\
& \mathrm{r}=1-\frac{6 \cdot \sum_{i=1}^{n} d_{i}^{2}}{n^{3}-n} \quad \text { where by } \mathrm{di}=\mathrm{r}_{\mathrm{x}}-\mathrm{r}_{\mathrm{y}}
\end{aligned}
$$

\section{Materials and methods}

The institutions of the European Union are committed to preserving the price stability. The European Central Bank (ECB) is in charge of price stability in the European Union and the Eurozone. According to Article 105 of the Maastricht Treaty, the main task of the ECB is to maintain price stability, stating that "without prejudice to the ECB's price stability, the ECB will support the general economic policy of the Community" (Jovanović, 2016). The monetary policy of the ESCB is also aimed at maintaining price stability, as set out in Article 127 of the Treaty on the Functioning of the European Union (ECB, 2017). With low inflation being their primary goal, the ECB has other tasks ${ }^{4}$ to define and apply

4 Target price stability level (inflation rate) was 2\% in 2015, 2016 and 2017. That was the period ECB fought against deflation. 
monetary policy, to maintain and manage the payment system and foreign exchange reserves of member states, as well as to conduct foreign exchange operations. There are several reasons for maintaining price stability, but the priority is a stable euro.

Price stability is included in several common policies of the EU. The production of agricultural products at "acceptable", i.e. "reasonable" prices is part of the Treaty of Rome. For example, Articles 32-38 of the EC Treaty regulate the legal foundations of agricultural policy (Popović, 2016). Article 33 defines five objectives of the CAP. One of the given objectives is "the supply of agricultural products and food at the socalled reasonable prices" (Popović, 2016). Thus, the first objectives of the CAP are clearly determined by the price policy and consumer interest. Since then to the point of revised objectives, the "acceptable" or "reasonable" prices persist, and are one of the conditions for the existence of the CAP. Revised and updated objectives, alongside with the old ones, contain new relevant information related to sustainable development, diversification, changes in the payment system, strengthening the regional approach with emphasis on rural development, competitiveness increase, etc. Practice has shown that price stability in the production of agricultural products and foods is maintained as the founding goal of the CAP.

The success of monetary and agricultural policy in the European Union reflects the movement of the general price level and prices of agricultural products (Chart 1).

Figure 3. Trends for the general level of inflation in the EU and prices of agricultural products

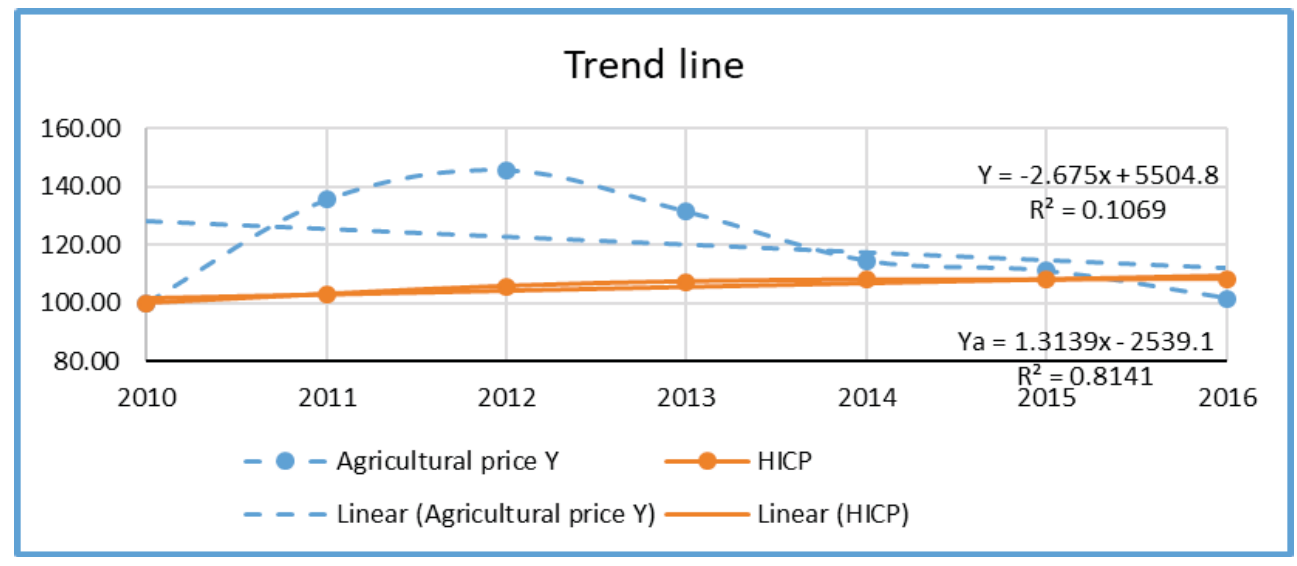

Source: Representation by the authors

In the period observed, the EU faced deflation announcements. The general price level is low but maintains constant growth. Only at the beginning of 2017, targeted inflation of $2 \%$ is achieved. During this period, notably high oscillations in the prices of agricultural products were observed (record level was achieved in 2012). The trend in the price of agricultural products is favourable as per the trend line (in 2016 the price index is lower than the general price level). The table suggests that price stability is favourable, at least when referring to the period observed. 


\section{CAP Support and price stability in agriculture: correlation and regression analysis}

The attitude towards prices in agriculture bears a particular social significance. Although this area contributes little to GDP, its importance is higher in terms of consumption and real wages, as well as complementarity with other industries. CAP creators insist on price stability, which is why it is not surprising that the issue of price support is unavoidable in almost any of the CAP reforms. Robert Ackrill pointed out that price support has the biggest impact on the EU budget. He even takes an extra mile and proves that price support is probably more useful than export support.

The question asked is: how much do allocations for CAP contribute to price stability? That is, whether the prices of these products are increasing faster than the general price level or even faster than some other industries? Hypothetically, the support affects the stability of prices of agricultural products and food. One of the methods is to compare the allocations in this area, as well as to compare the prices of agricultural products and food. Secondly, the correlation and regression analysis shows to which extent the allocations for CAP, as an independent variable, affect the prices of agricultural products as a dependent variable. The following table has been prepared in that respect.

Table 1. Total allocations for agriculture and prices of agricultural products (2008-2014)

\begin{tabular}{|l|r|r|r|r|r|r|r|r|}
\hline \multicolumn{1}{|c|}{ EU / Year } & $\mathbf{2 0 0 7}$ & $\mathbf{2 0 0 8}$ & $\mathbf{2 0 0 9}$ & $\mathbf{2 0 1 0}$ & $\mathbf{2 0 1 1}$ & $\mathbf{2 0 1 2}$ & $\mathbf{2 0 1 3}$ & $\mathbf{2 0 1 4}$ \\
\hline $\begin{array}{l}\text { Total allocation for } \\
\text { CAP (billion EUR) }\end{array}$ & 51643 & 56827 & 57186 & 58643 & 58389 & 59347 & 58852 & 57994 \\
\hline $\begin{array}{l}\text { Total allocation for } \\
\text { CAP (2010=100) }\end{array}$ & 88,06 & 96,90 & 97,51 & 100 & 99,57 & 101,2 & 100.36 & 98,89 \\
\hline $\begin{array}{l}\text { Total price of } \\
\text { agricultural } \\
\text { production } \\
\text { (2010=100) }\end{array}$ & - & 96,9 & 99,4 & 100 & 110,6 & 117,3 & 120,4 & 112,4 \\
\hline
\end{tabular}

\section{Source: Representation by the authors based on Eurostat ${ }^{5}$}

The data from the table show that since year 2008, the support to agricultural production has been stagnating and has ranged from 57 to 59 billion euros a year (in 2007 it amounted to 51.6 billion euros). Thus, the outbreak of the crisis (USA, 2008) and its "overflow" to the EU (2009) did not jeopardize the allocation for the CAP. On the contrary, in year 2008, funds for the CAP were increased by about $10 \%$ to approx. 57 billion euros. However, there were attempts to reduce the CAP budget. For the period 2014-2020, the United Kingdom proposed a reduction of 50\%, which would be a reduction of about 200 billion euros for the CAP over the seven-year period (Agrafacts, 2012). If such proposal had passed, it would affect the prices of agricultural products and food in the EU.

5 Eurostat is missing data for certain years 
From 2008 to 2013, prices of agricultural products were rising rapidly. The escalation of the global crisis was preceded by a global increase in the price of agricultural products and food in 2006/2007, which was transferred into the EU by the "spillover" effect. Calming of agricultural products' and food prices started only in 2014.

Regression analysis: the regression function indicates a positive link between the observed variables $(y=4,61 x-349,33)$. Thus, the movement of the variables is consistent with the results of the correlation and regression analysis as there is a medium strong correlation between the observed variables. Pearson correlation coefficient is $r$ $=0,761056$, which indicates that CAP allocations follow price movements to some extent, thus affecting price stability ${ }^{6}$. Other results of correlation and regression analysis: standard error of linear regression is $=6,662219071$ whereas Spearman's rank correlation coefficient is 0,821429 . The conformity of the interconnection between the variables is also shown by the dispersion diagram.

Figure 4. Dispersion diagram for agriculture and the prices of agricultural products

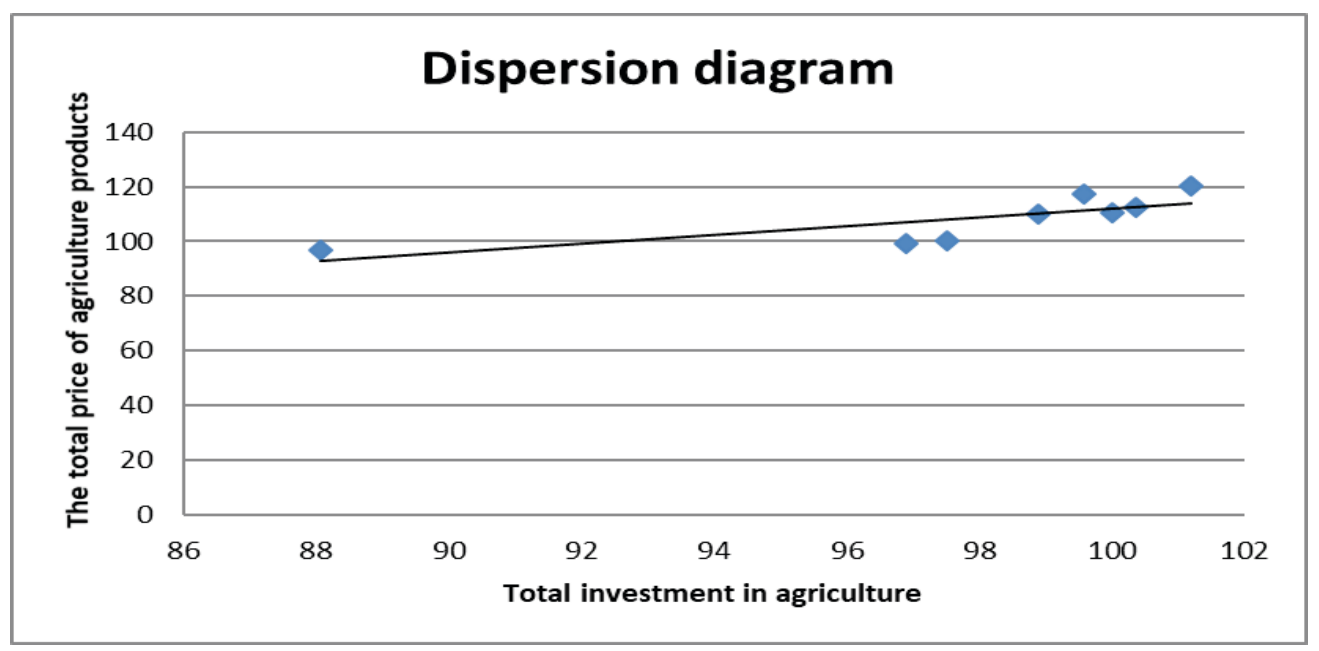

Source: Authors'calculations based on Table 1.

Shift analysis. For the purpose of a more realistic analysis, the data on the prices of agricultural products are shifted 1 year in advance. Due to the length of the production and sales process, the prices of these products are recorded only after a certain period (assumption: shift is 1 year). Therefore, the allocations for agriculture in year $n$ result in price effects in $n+1$ year. The analysis is more reliable as the correlation coefficients are higher and the standard error is lower, as can be seen from the results of dispersion diagram:

6 The absolute value of the correlation coefficient determines the strength of the relationship between the observed variables. For $|\mathrm{r}|=1$ there is a total correlation, for $0.8 \leq|\mathrm{r}|<1$ strong correlation, for $0.5 \leq|\mathrm{r}|<0.8$ moderate correlation, for $0.2 \leq|\mathrm{r}|<0,5$ relatively weak correlation, weak correlation, $0<|\mathrm{r}|<0.2$ very weak (insignificant) correlation, and finally for $|\mathrm{r}|=1$ there is a complete absence of correlation. 
Table 2. Results of correlation and regression analysis

\begin{tabular}{|l|l|}
\hline Correlation & 0,766551056 \\
\hline Pearson Correlation Coefficient & 0,766551 \\
\hline Spearman rank Correlation & 0,928571 \\
\hline Standard error of linear regression & 6,034473794 \\
\hline Regression function & $\mathrm{y}=1,59 \mathrm{x}-47,24$ \\
\hline $\mathbf{N}$ & 8 \\
\hline
\end{tabular}

Source: Representation by the authors

Comparison of the results of the analyses both with the shift and without the shift shows that the latter version shows a higher level of correlation between allocations for the CAP and the movement of prices of agricultural products. For Pearson correlation coefficient it is slightly higher and amounts to $r=0,766551$, whereas Spearman rank correlation coefficient shows a significantly higher level of variation of the variables. Other results of correlation and regression analysis: the standard error of linear regression is lower than in the former (first) version and is $=6,034473794$ while the regression function shows a positive relationship between the variables, or $y=1,59 x-47,24$.

Figure 5. Dispersion diagram for agriculture allocations and prices of agricultural products

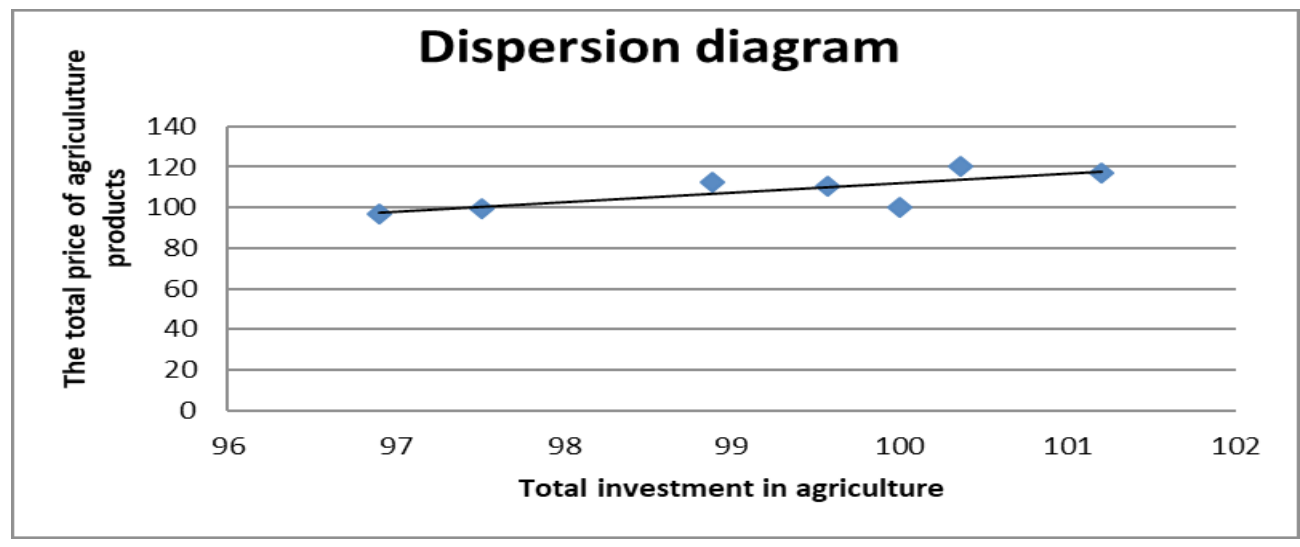

Source: Authors' calculations based on version 2.

\section{Results and discussions}

The analysis shows price relationships in the sectors of industry and agriculture. The hypothesis is that the prices of industrial products have an impact on the inputs of agriculture. The European Union has a developed chemical industry, machinery and vehicle industry, as well as a stable energy sector. With budget incentives, these are the key preconditions for the development of productive and modern agriculture. The strong influence of the industrial products' prices on the agricultural sector is reflected in the prices of agricultural products, even in the light of the support that EU agriculture receives from the CAP. Table no.3 was prepared in order to determine the link between the prices of industrial and agricultural products. 
Table 3. Total industrial prices and prices of agricultural products $(2010=100)$

\begin{tabular}{|l|r|r|r|r|r|r|r|r|r|r|}
\hline EU / year & $\mathbf{2 0 0 8}$ & $\mathbf{2 0 0 9}$ & $\mathbf{2 0 1 0}$ & $\mathbf{2 0 1 1}$ & $\mathbf{2 0 1 2}$ & $\mathbf{2 0 1 3}$ & $\mathbf{2 0 1 4}$ & $\mathbf{2 0 1 5}$ & $\mathbf{2 0 1 6}$ & $\mathbf{2 0 1 7}$ \\
\hline $\begin{array}{l}\text { Industrial } \\
\text { prices }\end{array}$ & 100,5 & 96,8 & 100,0 & 105,6 & 108,3 & 108,2 & 106,2 & 103,7 & 102,0 & 105,3 \\
\hline $\begin{array}{l}\text { Agricultural } \\
\text { products' } \\
\text { prices }\end{array}$ & 96,9 & 99,4 & 100,0 & 110,6 & 117,3 & 120,4 & 112,4 & 109,8 & 108,7 & - \\
\hline
\end{tabular}

Source: Representation by the authors based on Eurostat

The insight into the table and the comparison of data indicate a faster rise in the prices of agricultural products in relation to the price growth of industrial products. This is particularly noticeable since 2010, when every year prices in agriculture record a cumulatively faster growth. There are many reasons for such occurence. The primary one being that the prices of agricultural products are mainly affected by external effects and the general rise in world food prices. This means that the price level and their stability are affected neither by the ratio of aggregate supply and demand for agricultural products, nor the CAP measures, which also indicates an uneven cumulative price index of agricultural products.

Regardless of the faster price increase of agricultural products in relation to the industry, the correlation analysis shows a high level of interdependence on price developments in industry and agriculture. Therefore, the conclusion is that prices of industrial products in the European Union determine prices in agriculture, which is evident from the results of the regression analysis.

Table 4. Results of correlation and regression analysis

\begin{tabular}{|l|l|}
\hline Correlation & 0,926003619 \\
\hline Pearson Correlation Coefficient & 0,926003619 \\
\hline Spearman rank Correlation & 0,933333 \\
\hline Standard error of linear regression & 3,284621799 \\
\hline Regression function & $\mathrm{y}=1,90 \mathrm{x}-88,70$ \\
\hline $\mathbf{N}$ & 10 \\
\hline
\end{tabular}

Source: Representation by the authors

The regression function provides an insight into a positive relationship between the observed variables $(\mathrm{y}=1,90 \mathrm{x}-88,70)$. Movement of the variables is consistent, as can be seen from the results of the correlation and regression analysis. There is a strong correlation between the observed variables as Pearson correlation coefficient is $\mathrm{r}=$ 0,926003619, which explains that industrial prices have a dominant effect on the price stability of agricultural products. The other correlation and regression analysis results confirm the high consistency of the relationships between the observed variables: the standard error of linear regression is $=3,284621799$ whereas Spearman rank correlation amounts to 0,933333 . The relationship between the variables is also shown by the dispersion diagram. 
Figure 6. Dispersion diagram of prices of industrial and agricultural products

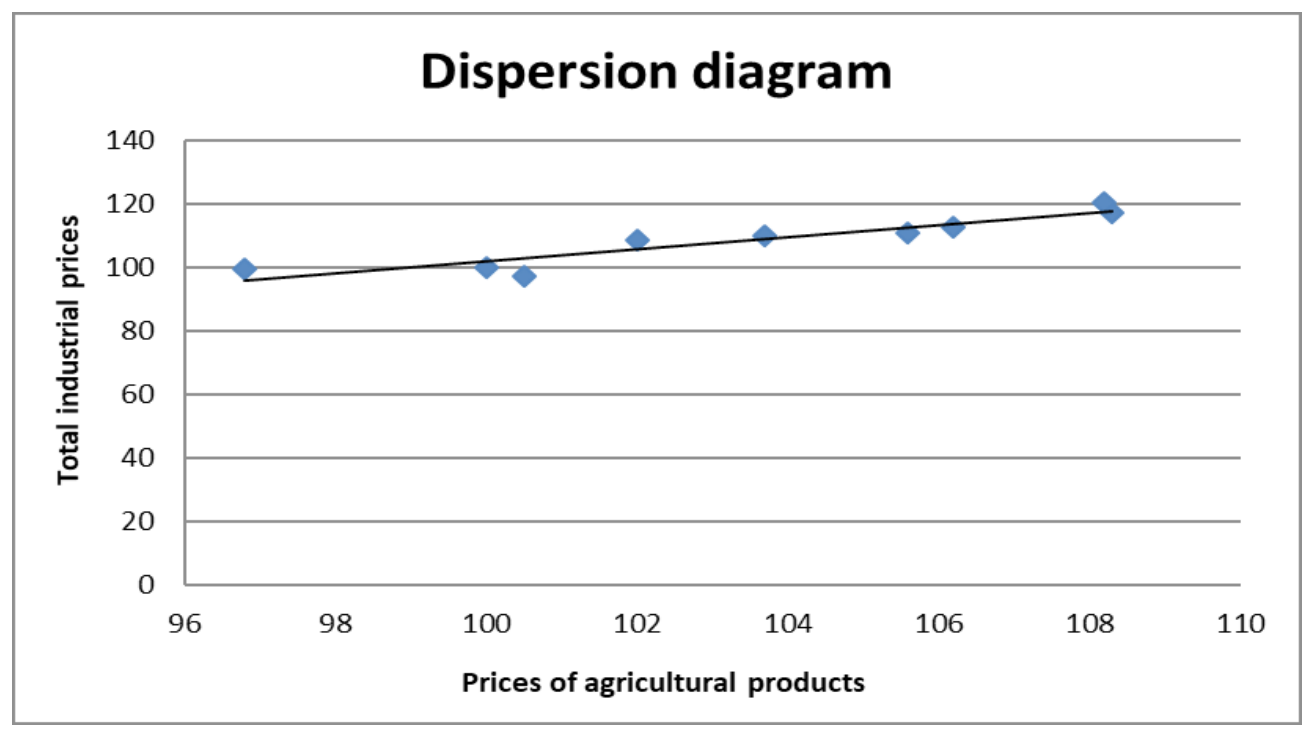

Source: Authors'calculations based on Table 3.

Production of cereals, milk and meat in the period 2007-2015 is uneven. Cereal production is the highest, while moderate but uneven growth is recorded only in milk production (record production registered in 2010 and 2015). From 2007 to 2015, cereals had the highest and continuous increase in prices. However, by 2014, the highest growth was recorded in milk production, but the prices of milk in 2015 dropped significantly (by 20 index points). The reason is the abolition of production quotas for European milk producers, and transition to free production on 1 April 2015. The production quotas within the CAP had been applied for as many as three decades, and despite the antagonism demonstrated by some partakers, they have yielded good results in the field of production, productivity, competitiveness and milk prices. Therefore, Romuald Schaber, the head of the European Milk Board, said that " The changeover to a free market economy of milk and dairy products is dangerous because, due to surplus in milk, large producers will dictate terms and milk prices will drastically decrease" (Popović, 2016). This estimate has been confirmed through a large increase in production and a further drop in milk prices in 2015.

The production and prices of milk and basic agricultural products are shown in the following table.

Table 5. Production and prices of beef, milk and cereals

\begin{tabular}{|c|c|c|c|c|c|c|c|c|c|}
\hline \multicolumn{10}{|c|}{ Production and prices of beef, milk and cereals (1000t) } \\
\hline $\begin{array}{l}\text { EU / } \\
\text { year }\end{array}$ & 2007 & 2008 & 2009 & 2010 & 2011 & 2012 & 2013 & 2014 & 2015 \\
\hline Beef & 8.258 & 8.130 & 7.766 & 7.565 & 7.610 & 7.579 & 7.271 & 7.421 & 7.583 \\
\hline Milk & 151.824 & 153.656 & 152.677 & 150.869 & 149.928 & 153.042 & 159.026 & 164.837 & 168.145 \\
\hline
\end{tabular}




\begin{tabular}{|c|c|c|c|c|c|c|c|c|c|}
\hline \multicolumn{10}{|c|}{ Production and prices of beef, milk and cereals (1000t) } \\
\hline Cereals & 61.186 & 59.498 & 55.451 & 56.594 & 58.108 & 57.956 & 57.852 & 57.437 & 61.186 \\
\hline \multicolumn{10}{|c|}{ Prices of beef, milk and cereals } \\
\hline Beef & 111,00 & 110,2 & 102,2 & 100,0 & 110,6 & 119,6 & 122,3 & 115,8 & 110,4 \\
\hline Milk & 100,6 & 101,9 & 101,2 & 100,0 & 99,4 & 101,4 & 105,4 & 109,3 & 111,5 \\
\hline Cereals & 102,2 & 98,9 & 97,6 & 100,0 & 106,6 & 109,5 & 114,0 & 114,7 & 114,6 \\
\hline
\end{tabular}

Source: Representation by the authors based on Eurostat

The relationship between supply and demand is the basic economic pattern. Accordingly, it is assumed that the growth of agricultural products leads to lower prices, that is, prices drop or remain at about the same level. Because of the CAP measures and EU support, this pattern is questionable, but correlation and regression analysis have confirmed the set hypothesis, particularly on the example of the increase in supply (production) of beef and even milk. This is evident from the results of the correlation and regression analysis comparisons shown in Table 6.

Table 6. Correlation coefficient for meat, milk and cereals

\begin{tabular}{|l|l|}
\hline Correlation meat & $-0,35072$ \\
\hline Correlation milk & 0,193994619 \\
\hline Correlation cereals & 0,245556505 \\
\hline $\mathbf{N}$ & 9 \\
\hline
\end{tabular}

Source: Representation by the authors

The correlation measured by Pearson correlation coefficient for beef equals to $r=$ $-0,35072$. Correlation coefficient for milk is $r=0,193994619$, while correlation coefficient for cereals amounts to $r=0,245556505$. Therefore, the growth of meat production leads to a price drop. The relatively minor but negative correlation indicates the existence of a certain degree of negative elasticity of prices, that is, the increase in the production of beef affects the decline in the price of that product. Even the minor positive correlation between milk production and milk prices, as well as the relatively poor correlation for cereals, mainly confirms, more than it contests the law of supply and demand. Moreover, moderate production growth is slightly correlated with the prices' movement of milk and cereals. It should be noted that cereals, unlike milk, are absolutely interchangeable goods and that there is a developed world market for these products. This practically means that a drastic drop in production may occur in some countries, with the market prices dropping nevertheless due to the impact of import prices. Finally, the correlation and regression analysis of the production and price of the given agricultural products is a confirmation that the EU through CAP measures affects total production, accomplishing one of the fundamental objectives: ensuring agricultural products for a single market at "reasonable / acceptable" prices. In doing so, the price stability of agricultural products and food is maintained. Indirectly, stability and growth in the production of agricultural products acts as a significant factor in overall price stability. 
Figure 7. Dispersion diagram of cereals production and price of cereals

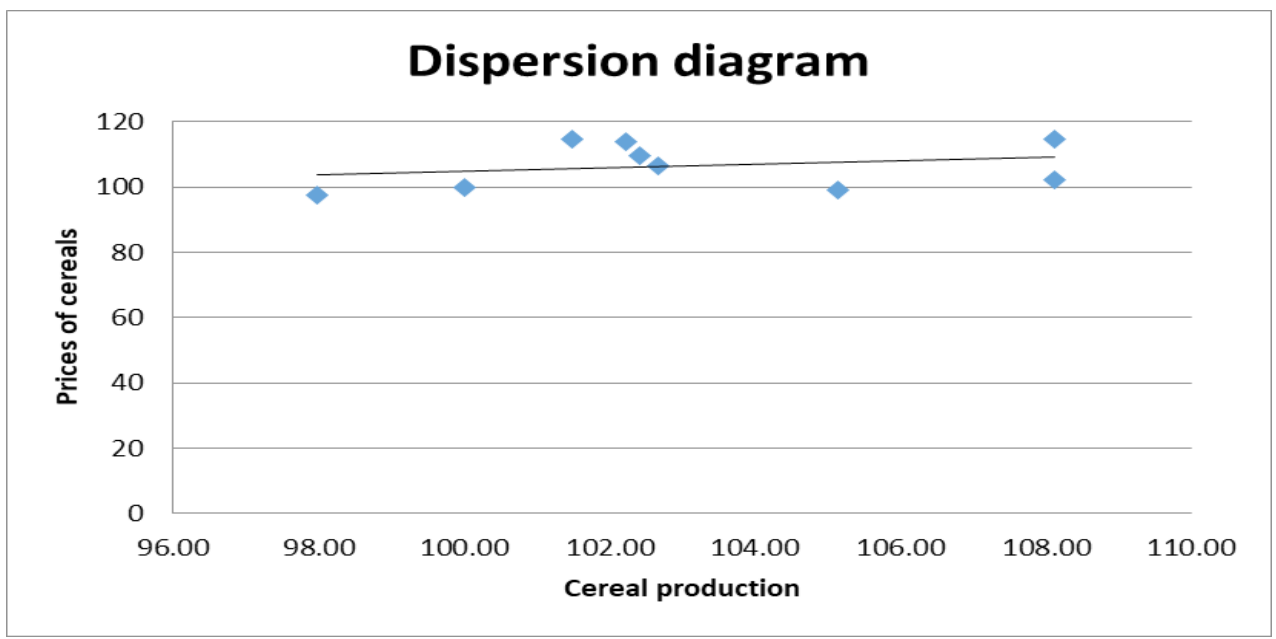

Source: Authors'calculations based on Table 4.

\section{Conclusions}

Since 2008 the CAP budget has been from 57 to 59 billion euros per year (in year 2007 it was 51.6 billion). Prices of agricultural products maintained their growth from 2008 to 2013. The global financial crisis $(2008 / 2009)$ was preceded by the price increase of agricultural products and food throughout the world (2006/2007).

Since 2010, prices of agricultural products and food in the EU have been relatively stabilized. The stable price period has started only since 2014. For the period from 2010 to 2016 the price comparison of agricultural products and the general price level indicated the inequality of the former in relation to the general inflation rate. However, the trend lines point to "price calming in agriculture," whose cumulative index approached the general price level in year 2015, and even dropped below the inflation rate in 2016.

The uneven movement of the price level of agricultural products is the result of multiple factors. The most common ones being: natural conditions for production, impact of world prices and the CAP support.

Correlation and regression analysis show that financial allocations from the CAP as independent variables affect the prices of agricultural products as a dependent variable. It has been proven that there is a positive relationship between the variables, which is evident from the regression equation $y=4,61 x-349,33$. There is a medium strong correlation between the variables as the Pearson correlation coefficient equals to $r=0.761056$.

This is a confirmation that allocations for CAP affect price stability in agriculture. Affirmation of the effect is also the high Spearman rank correlation coefficient of 0,821429 .

Prices in agriculture are growing faster than industry prices. Prices of industrial products 
affect the prices in agriculture. Correlation analysis indicates a high correlation on price movements in industry and agriculture, as evident from the equation $\mathrm{y}=1,90 \mathrm{x}-88,70$.

There is a strong correlation between the variables. Pearson correlation coefficient amounts to $r=0,926$ with Spearman coefficient being 0,933 thus proving that industrial prices are crucial for price stability in the EU agriculture.

CAP Measures and support are focused on the growth of production, i.e. of supply. The correlation and regression analysis of the production of beef, milk and cereals as independent variables and the price of these products as dependent variables confirmed the hypothesis that the growth of production affects the decrease (and maintenance on the same level) of the price of beef and even milk.

Pearson correlation coefficient for beef is $r=-0,35072$, for milk equals to $r=0,193994619$ and for cereals amounts to $\mathrm{r}=0,245556505$. Therefore, higher meat supply affects a price drop, whereas the growth of milk production, and to a certain extent - of cereals as well, maintains prices at the existing level.

General conclusion: correlation and regression analysis do confirm and evidence the effect of the CAP support on prices and production of agricultural products and food. Such practice enables the achievement of the founding objective of the Rome Treaty: to ensure sufficient quantities of agricultural products and food, but at "reasonable" or "acceptable" prices.

Although this subject is somewhat challenged by the public, it is a fact that CAP measures influence the price stability of agricultural products and food in the European Union.

\section{Conflict of interests}

The authors declare no conflict of interest.

\section{References}

1. Agrafacts. (2012). News for Agribusiness Executives, pp. 73-12, Brussels, Belgium.

2. Baffes John, Tassos Haniotis. (2016). What Explains Agricultural Price Movements? The Journal of the International Association of Agricultural Economists, Technical University of Madrid, Spain. https://doi. org/10.1111/1477-9552.12172

3. European Central Bank (2017). Objective of Monetary Policy, Frankfurt, Germany, Retrieved from https://www.ecb.europa.eu/mopo/intro/objective/ html/index.en.html ( July 23, 2017).

4. Hansen Henning Otte. (2016). Agricultural Policy Schemes: Price and Support Systems in Agricultural Policy. Reference Module in Food Science, Elsevier, pp. 286-294, Amsterdam, The Netherlands. https://doi.org/10.1016/B978-0-08-100596-5.01020-9

5. Helen L.Walls, Laura Cornelsen, Karen Lock, Richard D. Smith. (2016). How much priority is given to nutrition and health in the EU Common Agricultural Policy? Food Policy, Elsevier, Vol. 59, pp. 12-23, Amsterdam, The Netherlands. https://doi.org/10.1016/j.foodpol.2015.12.008 
6. Jean-Christophe Bureau, Johan Swinnen. (2018). EU policies and global food security. Global Food Security, Elsevier, Vol. 16, pp. 106-115, Amsterdam, The Netherlands.

a. https://doi.org/10.1016/j.gfs.2017.12.001

7. Jovanović N. Miroslav. (2013). The Economics of European Integration, Second Edition. Edward Elgar Publishing Limited, UK.

8. Kay BA, A. (1997). The MacSharry Reforms of the Common Agricultural Policy: A Challenge to Public Choice Theory. University of Nottingham. Nottingham, England. Retrieved from: http://eprints.nottingham.ac.uk/11838/1/339641.pdf

9. McMahon, J.A. (2007). EU Agricultural Law. OXFORD University Press. New York, SAD. Retrieved from: https:/www.e-elgar.com/shop/eep/preview/ book/isbn/9781781954621/

10. OECD. (2017). VALUATION OF AGRICULTURAL POLICY REFORMS IN THE EUROPEAN UNION : the common agricultural policy 2014-20. OECD.

11. Popović Goran. (2016). Economy of the European Union, Zavod za izdavanje udžbenika (eng. The Institute for Textbooks and Teaching Resources) East Sarajevo.

12. Quiroga Sonia, Cristina Suáreza, Zaira Fernández-Haddad, George Philippidis. (2017). Levelling the playing field for European Union agriculture: Does the Common Agricultural Policy impact homogeneously on farm productivity and efficiency? Land Use Policy, Elsevier, pp. 179-188, Amsterdam, The Netherlands. https://doi.org/10.1016/j.landusepol.2017.07.057

13. Rastislav Kotulic, Mariana Dubravska. (2015). Impact Of Management Tendencies Of The Common Agricultural Policy On The European Union Budget. Polish Journal of Management Studies, Czestochowa Technical University, Department of Management, vol. 11(2), pp 62-70, Polish. Retrieved from: http://pjms.zim.pcz.pl/PDF/PJMS112/Impact\%20of\%20 the $\% 20$ Management $\% 20$ Tendencies $\% 20$ of $\% 20$ the $\% 20$ Common $\% 20$ Agricultural $\% 20$ Policy $\% 20$ on $\% 20$ the $\% 20$ Budget $\% 20$ of $\% 20$ the $\% 20$ European $\% 20$ Union.pdf

14. Riccardi F. (2001). Bulletin Quotidien Europe. Agence Europe S\&A, pp 2-3. Bruxelles, Belgique.

15. Robert Ackrill. (2008). The CAP and its Reform - Half a Century of Change? EuroChoices, Special Section on the Common Agricultural Policy at Fifty and a Focus on World Food Commodity Prices, Vol. 7, Issue 2, pages 13-21, pp. 2.

16. Sol García Germán , Isabel Bardají, Alberto Garrido. (2015). Evaluating price transmission between global agricultural markets and consumer food price indices in the European Union. The Journal of the International Association of Agricultural Economists, Technical University of Madrid, Spain.https://doi. org/10.1111/agec.12209

17. T. Ostashko. (2016). "Agri-food exports to the EU: outlook and goals," Economy and Forecasting. National Academy of Sciences of Ukraine, Valeriy Heyets, issue 1, pp 83-94. Kiev, Ukraine. Retrived from http://eip.org.ua/docs/EP_16_1_83_uk.pdf 